\title{
“92 UZBEK TRIBES" IN OFFICIAL DISCOURSES AND THE ORAL TRADITIONS FROM THE SIXTEENTH TO NINETEENTH CENTURIES
}

\author{
A. Malikov \\ Palacky University Olomouc \\ Olomouc, Czech Republic \\ azimmal2018@gmail.com
}

\begin{abstract}
Research objective: To identify the main variations in the use of the term "92 Uzbek tribes" in various contexts in the official discourses and the oral traditions from the sixteenth to nineteenth centuries.

Research materials: The sources mainly used in this study are historical works of Central Asian Persian-language authors from the fifteenth to nineteenth centuries: Muhammad Salikh, Fadhlallah ibn Ruzbikhan Isfahani, Mirza Muhammad Haydar, Hafiz Tanysh Bukhari, Muhammad Yusuf munshi, Abdalazim Sami, Mirzo Salimbek, Sadr-i Ziya, and archival materials of the ethnographer B. Karmysheva. As well, an unpublished version of the epic poem "Alpamish" and archival documents from the Central State Archive of the Republic of Uzbekistan were used.

The publications of Russian, Soviet, and post-Soviet specialists on the history of the 92 tribes - N. Khanykov, C. Valikhanov, A. Khoroshkhin, L. Sobolev, G. Potanin, V.V. Bartold, Akhmed Zeki Velidi Togan, P. Ivanov, B. Akhmedov, T. Sultanov, Peter Golden, Devin DeWeese, V. Trepavlov, W. Holzwarth, A. Alekseev, and B. Babadzanov are also analyzed in detail.

The results and the novelty of the research: The term "92 Uzbek tribes", which appeared in the fifteenth-century Dasht-i Qipchaq, began to be used with a variety of meanings in the following centuries depending on the political and cultural context. The significant role of the members of the tribes from the former Golden Horde in the political life of the Central Asian Khanates from the sixteenth century, through the migration of nomadic tribes from Dasht-i Qipchaq to Mawarannahr during the sixteenth century, and still with the foundation in the Central Asian Khanates of dynasties from the surroundings of these tribes in the eighteenth century, ensured the relevance and the relatively widespread use of the term "92 Uzbek tribes". For the semi-nomadic tribes of these khanates, belonging to the "92 tribes" meant in certain cases a privileged position and a higher socio-economic status. In certain cases, the expression "92 Uzbek tribes" was used with a political meaning to legitimize the ruling Uzbek dynasties of the Manghits and Mings. Moreover, following a long tradition possibly in relation to pursued political goals, it emphasized long-standing ties between Qazaqs, Noghays, Uzbeks, and Qaraqalpaqs. Along with the number 92, such numbers as the " 32 " and "96" tribes coexisted. However, distinct meanings were attached to them.
\end{abstract}

Keywords: Golden Horde, Uzbeks, Kazakhs, Central Asia, 92 tribes, Dasht-i Qipchaq, Shibanids, Bukhara, Qoqand khanate, discourses, legitimation

For citation: Malikov A. "92 Uzbek Tribes" in Official Discourses and the Oral Traditions from the sixteenth to nineteenth centuries. Zolotoordynskoe obozrenie $=$ Golden Horde Review. 2020, vol. 8, no. 3, pp. 515-532. DOI: 10.22378/2313-6197.2020-8-3.515532 
Acknowledgments: This work was supported by the European Regional Development Fund Project "Sinophone Borderlands: Interaction at the Edges" (CZ.02.1.01/0.0/0.0/16_019/0000791). My special thanks are extended to the editor and anonymous reviewers for their comments and remarks.

Without understanding the heritage of the Golden Horde, it is impossible to understand the peculiarities of the political development and the existing discourse on the use of certain political terms in post-Chingisid States. This topic is complex and includes many different issues, the solution of which is difficult due to the fact that there is a limited number of internal sources on the history of the Golden Horde. The term "92 tribes of Uzbek" used in the post-Horde states of Central Asia is one of the interesting aspects of their history.

Initially, the term "Uzbek" was a Politonym. The term "politonym" is also used to refer to the people living within a given political entity. A feature of the politonym was that if it was retained in a particular resettlement group for several generations, it meant that the self-name was an ethnonym [9, p. 46], i.e. it was argued that, in temporal terms, the polytonym was less stable than the ethnonym. An analysis of data from various sources indicates that the lifespan of a polytonym depends on a variety of factors, one of which is political. It should be understood, however, that the polytonym may be transformed into an ethnonym, or may be used with a different meaning depending on the context.

Historians, orientalists and ethnographers attached different meanings to the terms "Uzbek" and "92 tribes". The orientalist N. Khanykov was the first to provide a list of the 97 Uzbek tribes of the Bukharan Emirate on the basis of Uzbek traditions, which he interpreted from the ethnic point of view [22]. The same tradition was followed by the military orientalists A. Grebenkin (1840-1888) and A.P. Khoroshkhin, who studied the Uzbeks of the Samarqand region [59; 25, p. 252, 495-505]. A genealogical legend accompanying the list of "92 Uzbek tribes" was recorded by the ethnographer A. Divaev, Akhund Kurbanali, Ahmed Zeki Velidi Togan, etc.

The renowned ethnographer G.N. Potanin (1835-1920), who was a friend of the Qazaq scholar Ch. Valikhanov (1835-1865), found evidence of the spread of the legend about 92 tribes among the Qazaq tribes of Central Asia [44, p. 10].

The Tatar historian Kurban Ali-Khalidi (1864-1913) was the author of several published works on the history of Central Asia, including "Tavarikh-i hamsa-i sharqi". This source includes genealogies of different Turkic and Asian peoples, as well as Qazaq genealogies based on oral sources [30, p. 57-58].

V. Bartold, based on an analysis of written sources, explored the history of Uzbek tribes in ethnic and political contexts. He was the first to raise the question of the role of the representatives of Uzbek tribes in the state apparatus of the $\mathrm{Bu}$ khara Khanate [6, p. 388-399].

Zeki Velidi Togan (1890-1970) noted that in the Uzbek genealogies of 92 tribes available in the copies of manuscripts of the sixteenth-seventeenth centuries, there are some differences. Validi claimed that this genealogy lists the names of tribes of the Golden Horde era, i.e. before the separation of Manghit-Noghays and Qazaqs. Of the 92 tribes named, approximately 45 are part of modern Uzbek [43, p. 94-95]. He proposed that "Özbek Eli" meant Golden Horde. Turning to the trib- 
al organization, "Özbek" are referred to everywhere as "doksan iki boy Özbek" (Ninety-two tribes of Uzbeks) [43, p. 94]. According to Peter Golden, the mass of Jochid soldiery, an important element in the formation of the Noghays, Siberian Tatars, Qazaqs and Uzbeks, was associated with the name Uzbeg/Uzbek by the second half of the fourteenth century [15, p. 330].

P. Ivanov (1893-1942) claimed that the term "Uzbek" in Bukhara and in Khiva Khanate was used with an ethnic meaning and in order to denote Uzbek, while historians of the nineteenth century used the term "92 tribes (of Uzbek)" or sometimes collective "Uzbekiye" [19, p. 23]. The Uzbek ethnographer K. Shaniyazov sought to understand the meaning of the term " 92 tribes" in terms of ethnic history [52, p. 403].

Sultanov tried to identify the principles on which lists of Uzbek tribes were drawn up. He highlighted some principles that affected the location of tribal names in the lists, namely: 1) the clans and tribes that had been part of political associations or had been genetically related and were placed close to each other on the lists 2) the higher the tribe's ordinal number, the stronger the importance of this tribe in the political life of the area of the list [54, p. 51]. Undoubtedly, the difficult question, which is now impossible to solve, seems to be the problem of separation of the traditional and the new on each individual list.

Six lists of "92 Uzbek tribes" were found in the Zarafshan Valley and Dzizakh region by K. Daniyarov (1927-1991), containing various legends of the origin relating to the eighteenth - nineteenth centuries [13, p. 6-7]. As DeWeese noted, in the research conducted before 1990, the list of 92 tribes was studied, but the traditions and legends remained uncharted. He studied the process of Islamization of the Turko-Mongolian tribes of the Golden Horde and in this light analyzed certain tribal traditions. In his fundamental monograph, DeWeese analyzed myths about the origin and Islamization of the 92 tribes [12, p. 458-459]. According to one of the existing traditions, the adoption of Islam by the Khan of the Golden Horde, Özbek Khan, with the help of saint Sayyid ata, brought about the emergence of the identities of Uzbeks and Qalmaqs [12, p. 364].

Trepavlov contributed greatly to the study of the socio-political and ethnic history of Dasht-i Qipchaq in the fourteenth - seventeenth centuries. Studying the history of the Noghai Horde, he analyzed the data of various sources, archival materials and concluded about the relationship of the Noghais with the Uzbeks of the Khanate of Abu'l-Khayr Khan (1428-1468), including the Qazaqs [56, p. 475]. He argues that the first version of the list of ninety-two "Uzbek" tribes was drawn up in the fifteenth century [56, p. 478].

Holzwarth analyzed sources of the eighteenth - nineteenth centuries relating to the use of the terms "Uzbek" and "92 Uzbek tribes" in the official discourse of the Bukhara Khanate. He noted that in some sources the Uzbeks were depicted as a military estate. Elaborating Bartold's ideas, he studied the role of Uzbek tribal participation in the state apparatus and their tribal organization. He concluded that the long list of tribal names mentions of twenty groups on the right wing, and thirtytwo on the left wing [23, p. 330].

Babadzanov analyzed Qoqand sources, which reflect mythologized stories about 92 Uzbek tribes [5, p. 245]. He identified various ways of legitimizing the Uzbek Ming dynasty in the Qoqand Khanate and the use of the term 92 tribes by various Qoqand authors in the nineteenth - early twentieth centuries. 
Thus, the previous ones identify two major trends in the interpretation of the term 92 tribes and its semantics. Certain researchers associate it with the Golden Horde and its tribal structure, while others suggest the ethnic content of the term. This study will use other approaches in studying the issue. I argue that the term 92 tribes originated in the Jochid ulus as a polytonym, but in subsequent centuries it was used in different meanings in the post-Chinggisid states of Central Asia.

The sources of this research were lists of Uzbek tribes, archival materials of the ethnographic research of B. Karmysheva, stored in the scientific archive of N.N. Miklukho-Maklay Institute of Ethnology and Anthropology of the Russian Academy of Sciences, unpublished Uzbek versions of the poem "Alpamysh", stored in the scientific archive of the Institute of Language and Literature of the Academy of Sciences of Uzbekistan. The version of the epic poem "Alpamysh", recorded in the Qushrabat district of the Samarqand province of Uzbekistan from the narrator Rakhmatullo Yusuf ugli, contains valuable information about Uzbek tribes.

To date, more than 18 lists of 92 Uzbek tribes drawn up in the sixteenth nineteenth centuries are known. In this paper, I analyzed the least-studied lists drawn up by the Bukharan intellectual Sadr-i Ziya (early twentieth century) [46, pp. 229a, 231a], a representative of the Sufi brotherhood Abd Al-Qadir ibn Muhammad Amin (early nineteenth century), the regional historian of Urghut Mulla Kurmat (early twentieth century) [45], as well as from an unpublished list of tribes in Arabic, apparently at the beginning of the twentieth century and recorded by B. Karmysheva during field research in the Dzhizakh province [26]. In order to identify the peculiarities of the use of the term 92 tribes in different contexts, the works of Russian, Tatar, and Kazakh ethnographers who studied the region in the nineteenth - early twentieth century were analyzed.

\section{The issue of the appearance of the term 92 Uzbek tribes}

The nomadic and semi-nomadic Turkic and Mongol tribes were united into various political alliances in the past, consisting of varying numbers of clans and tribes. Apparently, the study of this problem is related to the issue of the socio-political organization of Dasht-i Qipchaq nomads, as well as the symbolic meaning that the term 92 tribes was equated with in subsequent epochs. Unfortunately, the volume of existing material to date does not allow an in-depth study of the relationship of the term 92 tribes to the socio-political organization of the Turko-Mongolian tribes of the Golden Horde. Sultanov counted the names of 62 tribes of the Jochid ulus of the thirteenth - fifteenth centuries, listed in the sources [53, p. 77].

The issue of the origin and the dissemination of the term "Uzbek" as the name of the people is considered to be complex and debatable. The earliest mention of the anthroponym "Uzbek" dates back to the twelfth century [61, p. 135]. Since the fifteenth century, in the written tradition of Mawarannahr, the idea of Islamization of the Turkic-Mongolian tribes of the Golden Horde under the reign of Uzbek Khan (1312-1341) has become popular and the widespread distribution of the name of the nation of Uzbek is linked to his name [7, p. 142]. V.V. Barthold argued that "the word Uzbek, as a folk name, subsequently, in the fifteenth century ceased to be used in Southern Russia and remained behind only one of the Central Asian regions, with the center in the Syrdarya" [7, p. 212]. A.A. Semenov believed 
that it was a myth created in a later period, as in the official documents of Uzbek Khan and Russian chronicles there is no news and references to the term Uzbek as self-described [47, p. 11-17]. Researchers suggest that as of the mid-1370s, the ideology of the unification of the Jochid ulus - the elevation of the Golden Horde began to be renewed as in the time of Özbek Khan. The population of the Left Wing was subsequently known under the name of Uzbek [38, p. 697]. Canadian researcher Joo-Yup Lee pointed out that "the designation Uzbek began to be used as a term denoting the nomadic people of the Jochid Ulus during the reign of Uzbek Khan" and further he emphasized that "it is not clear exactly when the designation Uzbek became fixed as the designation of the nomads of the eastern Qipchaq Steppe, nor when it stopped being used for those of the western Qipchaq Steppe" $[32$, p. 122, 124].

Closely related to this problem is the issue of the self-name or ethnonyms of the population of the Golden Horde in the fourteenth and fifteenth centuries. I argue that there probably was no single self-name of the inhabitants of this multiethnic state. Sources mention both local exoethnonyms and endoethnonyms (Tatars, Kipchaks, Bulgarian, etc.). Authors of different sources recorded different names for the population. Joo-Yup Lee supposed that "Tatar and Uzbek denoted the same Turko-Mongolian nomads of the Jochid Ulus or the Qipchaq Steppe during the post-Mongol period" [32, p. 74]. I assume that the term Tatars arose much earlier than the self-name Uzbek and was applied to not only the nomadic but also the settled population of the Golden Horde. I support the opinion that in the fifteenth century the name Uzbek was used as one of the politonyms - to refer to the nomadic inhabitants of the Golden Horde, who inhabited Dasht-i Qipchaq. After the seizure of power in Mawarannahr by the Shibanids in the early sixteenth century, the term Uzbek became one of the ethnonyms of the Turkic-speaking population of the Bukharan Khanate [35, p. 618] and Khorezm.

The term "92 Uzbek tribes" was recorded for the first time in the sources in the sixteenth century. It originated in all probability back in the era of Abu'l-Khayr Khan rule (1429-1468), when a powerful state was established in the territory of eastern Dasht-i Qipchaq and the nomadic tribes were united [4, p. 27], although the earlier period cannot be excluded. In the sixteenth - nineteenth centuries, lists of "92 Uzbek tribes" were drawn up, which defined both the internal status as well as the external status of these tribes in relation to the other population of the region.

In the sources relating to the era of the conquests of Muhammad Shibani Khan in Mawarannahr (works of Bannai, Muhammad Salikh, Fadhlallah ibn Ruzbikhan Isfahani, Zahiraddin Muhammad Babur, Safavid sources), the term 92 tribes is not found. It is likely that the use of this term in the official discourse did not correspond to the ideology of Muhammad Shibani Khan, who fought repeated wars with Qazaq Chinggisids and the tribes who supported them [14]. The goals of Muhammad Shibani Khan in the early sixteenth century were to conquer Mawarannahr and Khorasan, and it can be assumed that in their realization he neither had nor sought allies in Dasht-i Qipchaq. The Shibanid historian Muhammad Salikh did not use the term 92 tribes, but he applied the term Uzbek to distinguish the Uzbek from the Chaghatay [51, p. 111], which is, in this case, apparently talked about as a political factor - belonging to the Ulus of Chaghatay or Jochi [33, p. 63]. The sixteenth century historian Mirza Muhammad Haydar, describing the events of the 1490s, mentions the Uluses of Mughal, Uzbek, and Chaghatay [41, p. 189-190]. A similar 
tradition of classification was followed by the historian of Shibani Khan, Ibn Ruzbikhan [14, p. 102-103].

Muhammad Salikh mentions the members of the 19 tribes that participated in the Muhammad Shibani Khan military actions [54, p. 10]. The Bukhara author of Hafiz Tanysh Bukhari in the second half of the sixteenth century mentions the 34 tribes, [21] and lists the names which did not exist in Mawarannahr during the epoch of Muhammad Shibani Khan. The analysis of sources shows that there were migrations of nomadic tribes from the sub-Syrdarya steppes to the oases of Mawarannahr at a later time [54, p. 18]. The worsening of climatic conditions in the north of Central Asia in the fifteenth - sixteenth centuries led to the increase of migration flows of the nomadic population to the south to the Aral Sea region and the sub-Syrdarya regions [36, p. 235-236], and possibly also to the internal oases of the region. Certain nomadic groups remained to serve the Shibanids and then the Ashtarkhanids. There was also a process of migration to the steppe. Thus, throughout the sixteenth century, the number of Dasht-i Qipchaq tribes in Mawarannahr increased and this factor reinforced the ideological side of the wider use of the term "92 tribes of Uzbek".

The earliest lists of mythological genealogical traditions of the 92 Uzbek tribes were compiled in the first half of the sixteenth century, which were included in the work of the Farghana author Sayf ad-Din Akhsikandi "Majmu' at-tavarikh". There are several lists of this work, which date from the end of the eighteenth to the first half of the nineteenth century [37, p. 8, 202]. Muhammad Shibani Khan is not mentioned at all, however, in this manuscript, the author is hostile to his grandfather Abu'l-Khayr Khan [50, p. 30]. There is therefore another version of the mythologization of the history of the Uzbek tribes.

The Bukharan historian Muhammad Yusuf munshi provides valuable information in his essay about the settlement of Uzbek tribes and their role in the militaryadministrative apparatus of the Bukhara Khanate in the seventeenth century [42].

Significant tribal migrations from Dasht-i Qipchaq in the sixteenth - seventeenth centuries updated the topic of 92 tribes as a certain type of legitimation of incoming tribes, followed by their absorption into the Bukhara Khanate, including complex processes of determining their economic status, public service of their ordinary elite, military service, etc.

\section{Official discourses on 92 Uzbek tribes}

The official discourses on the use of the term 92 tribes of Uzbek are the official documents, letters, official ceremonies where the term was heard.

Simultaneously, the term "92 tribes" was used in at least four meanings in the official discourse of the sixteenth - first half of the nineteenth centuries.

The first was used as the designation of Uzbek tribes of the region. In the sources of the second half of the seventeenth century, the expression "92 Uzbek tribes" is used in relation to the part of the population of Bukhara Khanate territory [42, p. 163]. As of the seventeenth century, there was an increase in the role of semi-nomadic Uzbek people in political life, as well as an increase in tribalism and separatism. Under such conditions, the seventeenth century poet Turdi called for the unity of the "92 tribes of Uzbeks" in his poem [60, p. 166]. When describing the hostilities between the Qtay Qipchaqs and Bukhara troops in the nineteenth 
century, it is noted that "(all) 92 tribes of Uzbek bit a finger of amazement" [19, p. 72]. Speaking about Nasrullah's reign (1827-1860), Bukharan historian Muhammad Ya'qub notes that all "92 tribes of Uzbek" expressed their readiness to serve the new Amir [19, p. 79]. Amir Haydar, in the letters to the governor of Karshi of the early nineteenth century, used the term 92 tribes - the firqa [23, p. 345]. For the semi-nomadic tribes of the Bukhara Khanate, the term " 92 tribes" served as a symbol of group or tribal solidarity, and meant a connection with the state's ruling military-political elite.

The second was one of the factors of legitimation. There is a letter addressed to King Akbar and sent by Abdullah Khan (1583-1598). He informed him that all the 92 Uzbek tribes and the Qazaq, Qirghiz, and Qalmuqs had been subjugated [16, p. 322]. It can be assumed that in the mid-eighteenth century, when the nonChinggisid dynasties of the Manghits and Mings came to power, they faced the problem of political legitimation [29]. This is in all probability why the use of the expression to control the 92 tribes meant an attempt to establish a connection with the Chinggisid legacy. The ruler of Bukharan Khanate, Daniyal ataliq, used the term 92 Uzbek tribes in diplomatic correspondence in 1781 [7, p. 465]. In the second half of the nineteenth century, the term 92 tribes continued to be used in the diplomatic correspondence of the Bukharan Emirate. In a letter written in spring 1868 on behalf of the Bukhara beks and addressed to the General-Governor of the Turkistan GovernorGeneralship, K. Kaufman, it was stated that "92 tribes constitute the population of Bukhara" [58, f. I-1, op. 34, d.8, 1.138]. The term "92 tribe" was used during the sacral ritual at the coronation (the rite of ascension to the throne) of Bukhara amirs from the Manghit dynasty. According to the Bukhara official and historian Mirza Salimbek, "On 14 November 1885 Sayyid Amir Abdulahad-Khan arrived from Karmina and entered the Ark of noble Bukhara. Common and noble people, ulema and military commanders gathered on Monday [in the Ark] and according to the law of Chinggis, according to the rules of Timur and according to the yasa of Mongols of the heir to the throne, the prince was placed on the white felt of his ancestors, and petty officers of ninety-two Uzbek tribes raised him from four sides, put him on the royal throne and declared him ruler (padishakh)" [40, p. 82-83]. Thus, the use of the term " 92 Uzbek tribes" in political rhetoric meant a commitment to a certain political tradition, the origins of which go back to the Abu'l-Khayr Khan epoch, and possibly also to an earlier period.

The third was a symbol of the former unity of certain nomadic and seminomadic tribes of the eastern part of Jochid ulus. The mainstreaming of the unity of 92 tribes as of the second half of the sixteenth century may be due to the growth of political influence and separatism of the semi-nomadic tribes of the Central Asian Khanates, and the political weakness of the Khanates, forced by the strengthening of the neighbouring states to seek diplomatic and ideological ways to find allies among the nomadic tribes of Central Asia.

It is known that the representatives of the ruling Uzbek Ming dynasty in Qoqand Khanate in order to legitimize their rule mythologized their history and associated their origin with Timurid Babur (1483-1530). However, after the defeat of the Qoqand Khanate by the Bukharan Amir Nasralla in 1842, there was a breakdown of the balance of political forces [5, p. 183], which led to the strengthening of nomadic elements - Qipchaqs and Kazakh tribes in the military-political history of the extensive possessions of the Qoqand Khanate. The new situation required a common idea that would bind the different nomadic groups of the state in order to 
ensure stability and reduce separatism and tribalism. Unlike the Bukharan Emirate, more detailed mythologized stories about the 92 Uzbek tribes are found in the official stories of the Qoqand Khanate, which was apparently due to a political factor. In this context, the term "92 tribes" was used among the ruling political elites of the Qoqand Khanate, and was also distributed among Qazaqs and Qaraqalpaqs. In Qoqand political terminology, the appeals to the Qirghiz by khan and the ruler of the Qoqand Khanate, Alimqul in 1864 mention the name "92 tribes" that live in harmony. In another document, Alimqul addressing the Qirghiz tribe Sarybagysh states that "by the will of the Almighty and Unlimited God, 92 nomadic tribes were humiliated (entered into strife) between themselves" [48, p. 89]. Alimqul, who intended to unite the steppe tribes of the region, propagandized the idea of the "unification of 92 nomadic tribes in his letters to the aristocracy of the Qazaq and Qirghiz tribes" [5, p. 245]. The Qoqand Khanate included significant territories inhabited by nomadic tribes of Qazaqs, Qirghiz for whose unification, along with Islam, the idea of the 92 tribes was used.

The fourth was in the designation of those tribes and clans that may have been entitled to some privileges by the reigning elites of the Central Asian Khanates. The problem of the role of the nomadic population in the political system of the Bukhara Khanate remains insufficiently studied. It can be noted that in the age of Ashtarkhanids, so-called yurts (within which there were nomadic tribes) were located within the administrative units (tumans) of the Bukharan khanate. Tumans were divided into khazara and buluks [2, p. 136]. Management and any kind of deployment of handouts and taxes, as well as recruitment into troops were only carried out among the Uzbeks on the basis of a generic characteristic [19, p. 23]. Military service in the Bukharan Emirate, which was dominated by the Uzbeks, also influenced the association of the term "92 tribes" with the military organization. The Bukhara historian Abdalazim Sami mentions Yuldash ishiq-aqa-bashi and Tughaymurad ishiq-aqa-bashi, authoritative Manghit military commanders, ... known "in the army of ninety-two [tribes] by boldness and courage" [39, p. 91-92]. Permanently settled (urban and rural) residents were designated by the term "fuqara" as opposed to "ilat" (nomads or semi-nomads who have preserved ancestral divisions) [19, p. 23].

The Ming tribe is mentioned in all the traditional lists of Uzbek tribes and occupies the highest places, which speaks not only of multiplicity and power, but also of a long tradition. Most of the compilers of "lists of 92 tribes" followed it. In the "Majmu' at-tavarikh" list of the sixteenth century and in the "Tuhfat at-tavarikh" list of the nineteenth century, the Mings are in the first place [54, p. 48]. In the list of Uzbek tribes found in the Tashkent region and published by A. Divaev, the Mings occupy the first place, [11] as well as in the Urghut list, compiled most likely in the second half of the nineteenth or early twentieth centuries [45, p. 10]. In the list of Ch. Valikhanov, the Mings are also in the first place [62, p. 553]. Only the Bukhara lists of " 92 tribes" differ, where the ruling Manghits are placed first and the Mings are placed second. In the list of N.V. Khanykov (1843), for example, compiled on the basis of the data from the Bukharan Emirate, the Mings are in the second place after Manghits [22]. According to a list compiled by the Bukhara intellectual Sadr-i Ziya in Bukhara in the early twentieth century, the Mings are in the second place after the Manghits [46, p. 229a, 231a]. The Qoqand historian Avaz-Muhammad Attar Qoqandi mythologizes the history of the 92 tribes, linking them to the Prophet $\mathrm{Mu}$ - 
hammad, the Turks, the caliph Abu Bakr, and the Tulash-baba. Due to the enmity of the Qoqand Mings with the Bukhara Manghits, the author probably does not include them in the list of tribes of "Uzbek" [5, p. 494-496].

Not all Bukhara authors placed the Manghits at the top of the list of tribes. In the essay "Majma al-ansab wa-1-ashdar" compiled by the Bukharan author Abd AlQadir ibn Muhammad Amin in the late nineteenth century, the genealogy of 92 Turkic tribes is placed, which includes a variety of clans from the Mings onwards, Yuz, Qirq, Olchin, Qalmaq, Oyrat, Tangut, Arlat, Arab, Barlas, Tatar, and Uyghur $[1$, p. 240]. Thus, the list contains Arabs who never lived in Dasht-i Qipchaq. It is known from the sources, however, that the Arabs formed a separate military unit in the Bukhara troops [2, p. 143], which were mainly composed of members of Uzbek tribes, so it is likely that the Arabs were also included in the list of 92 tribes.

In my view, the ethnic approach in studying the issue of 92 tribes is not fruitful and on the contrary it misleads researchers. According to the sources, the number 92 was combined with the other numbers 32 and 96, which were given importance depending on the era, cultural and socio-political context. In the discourse of the nineteenth century, the term "92 tribes" symbolized not only the tribes that came with Muhammad Shibani Khan in the sixteenth century, but also the close ties of the Central Asian tribes, which were part of the Qazaqs, Noghay, Qaraqalpaqs. It was a former political alliance of these tribes, but when united in case of danger they could represent a formidable force. It can be assumed that the lists of "92 tribes", if necessary, could be important in organizing the mobilization of the representatives of these tribes to the troops of the Bukharan and Kokand Khanates. Accordingly, they received certain privileges.

\section{"92 tribes" in the oral traditions of the population of Central Asia}

The term "92 tribes" in the oral traditions of the nineteenth century was used in at least four meanings.

The first was in a list which local Sufi sheikhs, Ishans, used to identify their murid groups to receive certain economic offerings from them. According to one of the legendary genealogies of 92 Uzbek tribes, each Uzbek tribe had its own saint Ishan. A long list of pirs - patrons of each tribe was given [11]. Certain holy sheikhs were recognized as ancestors of Uzbek tribal groups and parallels can be found among Turkmen. In one manuscript dating from 1903-1904, 92 Uzbek tribes are presented as descendants of an ancestor of caliph Abu Bakr's father [12]. The analysis of sources revealed that there was a tradition by which the history of nomadic Uzbek people had been connected with Baba Tükles (Tulash baba), who appears in the foreword to the lists of 92 Uzbek tribes found in Tashkent manuscripts. Baba Tükles acts as the leader of the community in the tradition of the Noghais, Qazaqs, and Uzbeks [12, p. 457]. In the late versions on the origin of Uzbeks, an image of Baba Tükles as a communal protector and patron spirit of Uzbeks appears. He is introduced as "Tulash Baba" in the preface to a listing of the "ninety-two Uzbek tribes" found in two manuscripts in Tashkent lists of the ninetytwo tribes [12, p. 457-458]. The list of 92 tribes, recorded by Karmysheva in the Dzhizakh province of Uzbekistan, also contains a similar legend including the name Tulash baba, but has some differences [26].

The second meaning of the term "92 tribes" was preserved in the oral tradition of some Qazaq tribes in the territory of modern Kazakhstan. Junghar aggression 
against Kazakh, Qirghiz, and Uzbek tribes in the seventeenth and eighteenth centuries resulted in the need to unite the population of Central Asia against the enemy. It can be assumed that these circumstances to some extent intensified the resuscitation of the idea of the unity of 92 tribes. A major role in maintaining the ties between the Bukhara Khanate and the Qazaqs was played by the Khwajas, especially from Sayyid-ata's lineage [24, p. 185-186]. It should be emphasized that the political situation, especially in the first half of the eighteenth century, was complex and contradictory. Under Junghar strikes, some Qazaq tribes invaded the territory of Bukhara Khanate and the leaders of the local Uzbek Keneges tribe tried to use them in the fight against Ashtarkhanids [24, p. 194-195]. In the second half of the nineteenth century, the oral tradition about 92 tribes was recorded by N. Grodekov: "The legend regarding the formation of the Kazak people, i.e. Qirghiz, from parts of different Uzbek tribes, still lives in the mouth of the people ... A list of 92 Uzbek tribes in different variants, called 'nasab namei uzbekiya', was distributed among the Qirghiz. The list of 92 tribes of Uzbek states that when 92 brothers became rich, their cattle began to mix. To mark the membership of the cattle, the brothers, when meeting between themselves, invented 92 signs, tamghas. The antiquity of tamghas is confirmed by the fact that many of the names of tribes, and even more frequently the names of knees, come from the names of tamgha patterns [10, p. 2-3]. In this case, an attempt is made to create a myth about the origin and related ties of the Qazaqs, Turkmen, Qaraqalpaqs, and semi-nomadic Uzbek. The Tatar historian Kurban AliKhalidi (1864-1913) provides a legend about a man named Uzbek, who had 92 sons: "tuksan ikki bauli uzbek". He also lists tribes: Ming, Yuz, Qirik, Jalayir, Qunghirat, Alshin, Nayman, etc. [30, p. 57-58]. The Kazakh educator Mashhur Zhusip Kopeev, based on Kazakh oral traditions, presented one of the genealogical versions about the origin of Central Asian peoples, according to which Kazakhs are the descendants of three men: Seilkhan, Zhailkhan and Elkhan. From Zhailkhan comes Maika and from him Uzbek and Syban. The three sons Ming, Yuz, and Qirghiz come from Uzbek. In Qazaq traditions it is noted that Qipchaqs consisted of ninety-two tribes (toksan eki bauli) [27, p. 111-112]. Thus, according to one Kazakh genealogical version, 92 tribes were associated with Qipchaqs, who dominated the territory of Dasht-i Qipchaq prior to the Mongolian conquest.

The third meaning of the term stressed the Noghay roots of real or mythological ancestors of some tribes. In the Turkic and Persian works of the sixteenth century, the inhabitants of the Nogai Horde were called Manghit Uzbek (uzbakan-i manghitu). In the sixteenth century, the lands of the Noghay horde were referred to as "Uzbekistan" in the hagiographical work, where the designation "Manghit Uzbeks" occurs often [12, p. 347]. In addition, subjects of the Qazaq Khanate appear in some sources as Uzbek-Qazaqs and (as early as the seventeenth century) Uzbeks [57, p. 254]. In later versions of the genealogical legend of the Uzbeks (Galliaral version), it was claimed that the ancestor of the 92 tribes of the Uzbeks was Noghay-mirzo [13, p. 77], which in our opinion suggests the spread of the version of Noghay roots among certain tribes of the Uzbeks [33]. Burns mentions families of Noghays in Bukhara who came from Russia [8, p. 371]. The term Noghay was also applied to the Volga Tatars. The commonality of the oral heritage of the Noghais, Qazaqs, Qaraqalpaqs, and nomadic Uzbek is confirmed by general epic poems. Qazaqs, Qaraqalpaqs and Uzbek, for example, had the epic "Alpamysh 
(Alpamys)" with a general story, and different variations of the epic "Idige" were found with the Bashkirs, Qazaqs, Qaraqalpaqs, Noghays, Turkmen, and Uzbeks $[18$, p. 143].

The fourth meaning of "92 tribes" began to be used by Russian-Orientalists purely in the ethnic terms after Central Asia became part of the Russian Empire, with Russian-Orientalists using the term "92 tribes" purely in the ethnic meaning. According to L. Sobolev, for example, the majority of people of the Zarafshan province were Uzbeks, and then Tajiks. The Uzbeks were divided into 92 tribes [49, p. 132]. A. Khoroshkhin argued that Uzbeks had 92 tribes or 92 baus. There were Uzbeks, and among them were settled, semi-nomadic, and nomadic people [25, p. 491-498].

Thus, by the nineteenth century, the term "92 Uzbek tribes" had been preserved as a symbolic term with a certain meaning, more as a traditional tribute. If one compares the designation of the term tribe in the sources, one can notice the difference between different traditions. Traditionally, the tribe or kin is often denoted in medieval Bukhara sources by the terms urugh, el. In the folk discourses about 92 tribes, the generally accepted term for referring to a tribe was the term bau, which was only applied when it was talked about 92 tribes [55, p. 42]. In the sources, the Arabic terms firqa ("part; sect") and qism were used most frequently when there was the formulation "ninety-two Uzbek tribes" [23, p. 345].

After the establishment of the power of the Russian Empire, socio-political and economic changes, the term "92 tribes" only acquired a purely symbolic, historical meaning. Under the influence of modernization processes in Muslim societies of the Russian and Ottoman empires, other types of identities arose and increased: Turk, Turkistan, which expanded the imaginary boundaries of Central Asian societies.

\section{The issue of 32, 92, 95, and 96 tribes}

In the sources of the sixteenth - nineteenth centuries there are various numbers of Uzbek tribes: 32, 92, 95, and 96. Researchers explain their use in different ways. In the sixteenth century source "Majmu' at-tavarikh", there is a legend about 92 tribes. However, in the same source the names of 95 tribes are indicated in the list of tribes [37;50].

The eighteenth century sources record both terms: 32 and 92 tribes. 32 tribes are mentioned by the nineteenth century authors A. Vamberi and A. Burns, which reveals the preservation of the tradition [8, p. 367].

V.V. Bartold (1869-1930) wrote that it was previously seen that there were 32 Uzbek tribes, then 92, and he argued that there was apparently a breakdown of tribes and an increase in their number [7, p. 465]. According to Togan, 92 tribes represented the tribal composition of the Golden Horde. Sultanov revealed that the term "32 tribes" existed during the era of the rule of Golden Horde's Toqtamish Khan (1378-1395) [54, p. 27].

The ethnographer G.N. Potanin (1835-1920) conducted ethnographic research within the territory of modern northern and north-eastern Kazakhstan. He revealed ideas of origin among a certain part of the Qazaqs, who claimed that the root of the Qazaqs originated from the Turks of Mongol descent, the Muslim faith, the Uzz tribe, and the felt-yurt of the three uok tribes. The Qazaqs claimed that during the time of Prophet Muhammad their ancestors Akashe, son of Nazir and Anes, son of 
Malik, also Akhtam-sufi and Imam-bair were adherents of the Prophet. The descendants who originated from them, having reproduced during the time of Abubakr Kababa, were called "Uzbek with thirty-two ropes" (otuz eeki bauli uzbek). The eldest was a thousand - Ming, the second - a hundred - Yuz, from the three sons of Yuz there originated our Kazakhs [44, p. 310]. In another publication, apparently based on another source, Potanin wrote "when talking about Qipchaqs, it is said: kipchak tuksan ikki bauli (Qipchaqs with 92 ties), they are as 92 tribes" $[20$, p. 74]. In the Qaraqalpaq genealogy-shejire, it was stated that the ancestor of the 32 tribal groups of Uzbek ( 32 bauli Uzbek) was a descendant of Zhailgan Nagadai, and Qaraqalpaqs originated from the 32 tribes [17, p. 485].

Sultanov wrote that there are obviously two separate lists of tribes [54, p. 28]. He argued that there were 32 officials in the social and political life of the Uzbeks of Central Asia, who were the representatives of individual tribes that had the greatest weight in the life of the country. The position of officials in the court environment was significantly dependent on their belonging to a particular clan or tribe [54, p. 51]. According to Holzwarth, 32 tribes belonged to the Shibanid tribal groups in the sixteenth century, and the 92 included all the Turko-Mongolian tribes of the region [23, p. 345].

Sultanov drew attention to the fact that in three lists of the same work "Majmu' at-tavarikh" there are 95 names of tribes instead of 92 . This makes it possible to argue that the general selection of names was arbitrary [54, p. 39]. The replacement of some names with others seemed to reflect the position and weight occupied by certain tribes during the period [54, p. 51], as well as the place of correspondence and personal views of the enumerator. Sultanov and other researchers believed that the number 95 was a mistake. It is possible that the historical roots of the oral tradition of 95 tribes are connected with the era of the Mongol Empire. The Secret History of the Mongols states that in 1206 the Mongolian ulus was administratively organized by Chinggis Khan into 95 minkats (thousands) with certain territories (nuntuk) which formed a number of territorial regions within the Chinggisid state [28, p. 158; 31, p. 217]. It is important to note two facts here. It is likely that the indicated number of 95 was later established in the oral tradition of nomadic tribes. The term thousand-minkat or Ming could have been used as the name of the tribe from which the early lists of 92 tribes traditionally began. The names of the Ming, Yuz (one hundred), Qyrq (forty) tribes, with which most of the lists of 92 tribes begin, were probably associated with the military organization of the Turkic-Mongol tribes. In later genealogical traditions, these tribes were considered to be related [34, p. 159-160].

In later popular tradition, there were particular interpretations of the number of Uzbek tribes, where the number 96 tribes appeared. This figure was recorded by Ch. Valikhanov and in some Uzbek epic poems - dastans. According to Uzbek traditions, the name of the first union, i.e. 96 tribes is here. There are three generations of Ming, Yuz, and Qyrq, under the common name Turk (these are the descendants of ancient Turks), Unaga, Unkaji, Jalayir, Saray, and others [62, p. 553].

As the archival material of B. Karmysheva and the information from one of the Uzbek versions of the poem "Alpamysh" indicate, the number 96 tribes was used, but with a different meaning. According to B. Karmysheva, in the past, 92 tribes of Uzbek were divided into fifteen bulaks with six in each [26]. Apparently, there was a tradition to divide it into 16 bulaks and as a result it turned out to be 96 . The epic 
"Alpamysh" presents the representations of Uzbek storytellers about the origin of Qunghrats. One version recorded in the Zarafshan Valley claims, for example, that the Qunghrats were one of 96 tribes (bov) of Uzbek men who were linked to the Turks who arrived in Jijdeli Baysun from the country of Shom (Syria). Each bov was divided into bek-led bulaks [3, 1. 1, 10, 256]. It is therefore not surprising that N. Khanykov cited 97 names of Uzbek tribes by the local source ("Nasab-NamaiUzbek") [22]. As noted above, the territories of the nomadic Uzbek tribes were located within the territorial-administrative units of the Bukhara Khanate (tumans, buluks, khazara), so it can be assumed that the number 96 appeared as a result of the combination of the state model of territorial administration with the nomadic one. It can be assumed that the number 96 tribes began to be used at a later time, probably as of the seventeenth century. It is possible that the origins of the use of a certain number of Uzbek tribes come from several cultural traditions.

\section{Conclusions}

Thus, the term "92 Uzbek tribes", which presumably appeared in the fifteenth century, began to be used over the following centuries with a variety of meanings depending on the political and cultural context. The significant role of the members of tribes from the Golden Horde in the political life of the Central Asian Khanates as of the sixteenth century, and then the foundation in the eighteenth century in the Central Asian khanates of dynasties from among these tribes ensured the relevance and relatively widespread use of the term " 92 Uzbek tribes". For the semi-nomadic tribes of these khanates, belonging to " 92 tribes" meant in certain cases a privileged position and a higher social, economic status, but with the obligation of military service. It should be noted that there were tribes that were permanently placed high on the 92 tribal list. It is also possible, however, to state the inclusion of new tribes in later lists. This indicates that there had been a manipulation to include or exclude a tribe from the 92 tribal list.

The term "Uzbek", originally a polytonym, gradually began to turn into an ethnonym. Nevertheless, in certain cases, it was used with a political meaning to legitimize the ruling Uzbek Manghit, Ming dynasties, and following a long tradition, perhaps the pursuit of political goals, which emphasized long-standing ties between Qazaqs, Noghays, Uzbeks, and Qaraqalpaqs. Along with the number 92, numbers such as 32, 95, and 96 tribes coexisted, the semantics and symbolic significance of which require more research. The interaction of the nomadic tribal organization with the state administrative-territorial system of administration led to the emergence of the number 96 in all probability in the seventeenth century. There is the possibility that the numbers 92 and 96 had symbolic significance, but certain periods of history were also used for practical purposes in the distribution of resources, pastures and military service in the Bukhara Khanate.

\section{REFERENCES}

1. Abd al-Kadir ibn Mukhammad-Amin. Mazhma‘ al-ansab va-1-ashdzhar. Istoriya Kazakhstana v persidskikh istochnikakh [History of Kazakhstan in Persian Sources]. Vol. 2. Vokhidov Sh.Kh., Muminov A.K. and Aminov B.B. (eds). Almaty: "Dayk-Press", 2005. 693 p. (In Russian) 
2. Alekseev A.K. Politicheskaya istoriya Tukay-Timuridov. Po materialam persidskogo istoricheskogo sochineniya Bakhr al-asrar [Political History of the Tuqai-Timurids: Based on the Materials of the Persian Historical Work Bakhr al-asrar]. St. Petersburg: St. Petersburg University Publ., 2006. 229 p. (In Russian)

3. Alpomish. The poem was recorded by the narrator Rakhmatullo Yusuf-ogli himself in 1968 in the Scientific Archive of the Institute of Language and Literature of the Academy of Sciences of the Republic of Uzbekistan. Inv. No. 1660. (In Uzbek)

4. Akhmedov B.A. Znachenie pis'mennykh pamyatnikov v izuchenii etnicheskoy istorii uzbekov [The significance of written sources in studying the ethnic history of Uzbeks]. Materialy $k$ etnicheskoy istorii naseleniya Sredney Azii [Materials for the Ethnic History of the Population of Central Asia]. Tashkent: Fan Publ., 1986, pp. 14-30. (In Russian)

5. Babadzanov B.M. Kokandskoe khanstvo: vlast', politika, religiya [The Kokand Khanate: Power, Policy, and Religion]. Tokyo-Tashkent, NIHU Program Islamic Area Studies Center, University of Tokyo Publ., 2010. 744 p. (In Russian)

6. Bartol'd V.V. Tseremonial pri dvore uzbekskikh khanov v XVII v. [The ceremonial at the court of the Uzbek khans in the seventeenth century]. Sochineniya [Writings]. Vol. II, Part 2. Moscow: "Science", 1964, pp. 388-399 (In Russian)

7. Bartol'd V.V. Raboty po istorii i filologii tyurkskikh i mongol'skikh narodov [Works on History and Philology of Turkic and Mongolian People]. Vol. V. Moscow: "Science", 1968. 760 p. (In Russian)

8. Burns A. Puteshestvie v Bukharu: rasskaz o plavanii po Indu ot morya do Lagora $s$ podarkami velikobritanskogo korolya $i$ otchet o puteshestvii iz Indii v Kabul, Tatariyu $i$ Persiyu, predprinyatom po predpisaniyu vysshego pravitel'stva Indii v 1831, 1832, $1833 \mathrm{gg}$. leytenantom A. Bornsom. [Travels into Bokhara. Being an Account of a Journey from India to Kabul, Tartary, and Persia. The Narrative of a Voyage on the Indus from the Sea to Lahore, Undertaken by Order of the Highest Government of India in 1831, 1832, and 1833. Lieutenant A. Burns]. Ch. 3. Kn. 1-2. Moscow, 1849. (In Russian)

9. Bromley Yu.V. Ocherki teorii etnosa [Essays on Ethnos Theory]. Moscow: "Science", 1983. 418 p. (In Russian)

10. Grodekov N.I. Kirgizy i kara-kirgizy Syr-dar'inskoy oblasti [Kyrgyzes and Kara Kyrgyzes of the Syrdarya Province]. Tashkent, 1889. 205 p. (In Russian).

11. Divaev A.A. O proiskhozhdenii uzbekov [About the origin of Uzbeks]. Turkestanskie vedomosti [Turkestan Journal]. 1900, no. 97. (In Russian)

12. DeWeese D. Islamization and Native Religion in the Golden Horde: Baba Tükles and Conversion to Islam in Historical and Epic Tradition. University Park (Penn.): Pennsylvania State University Press, 1994. 656 p.

13. Doniyorov Kh. Uzbek khalqining shazhara va shevalari [The Genealogies and Dialects of the Uzbek People]. Tashkent: Fan Publ., 1968. (In Uzbek)

14. Fadhlallah ibn Ruzbikhan Isfahani. Mikhman-name-yi Bukhara (Zapiski bukharskogo gostya) [Bukhara Guest's Notes]. Dzhalilova R.P. (tr.) and Arends A.K. (ed.). Moscow: "Science", 1976. 536 p. (In Russian and Persian)

15. Golden P.B. An Introduction to the History of the Turkic Peoples. Ethnogenesis and State Formation in Medieval and Early Modern Eurasia and the Middle East. Wiesbaden: Otto Harrassowitz, 1992. 497 p.

16. Haider, Mansura. Relations of Abdullah Khan Uzbeg with Akbar. Cahiers du Monde russe et soviétique. 1982, vol. 23, no. 3/4, pp. 313-331.

17. Zhdanko T.A. Karakalpaki Khorezmskogo oazisa [Karakalpaks of Khwarazmian oases]. Trudi Khorezmskoy archeologo-etnograficheskoy ekspeditsii [Works of the Khwarazmian Archaeological and Ethnographical Expedition]. Vol. 1. Tolstov S.P. and Zhdanko T.A. (eds). Moscow: USSR Academy of Sciences, 1952. (In Russian)

18. Zhirmunskiy V.M. P.M. Melioranskiy i izuchenie eposa "Edigey" [P.M. Melioranskiy and studying the epos "Edigey"]. Turkologicheskiy sbornik 1972 [Turkological Collection 1972]. Moscow: "Science”, 1973, pp. 141-185. (In Russian) 
19. Ivanov P.P. Vosstanie kitay-kipchakov v Bukharskom khanstve in 1821-1825 gg. Istochniki i opyt ikh issledovaniya [The uprising of the Kitay-Kipchaks in the Bukhara Khanate of 1821-1825. Sources and experience of their research]. Trudy Instituta Vostokovedeniya. [Proceedings of the Institute of Oriental Studies]. Vol. XXVIII. Moscow; Leningrad: Academy of Sciences of USSR, 1937. 131 p. (In Russian)

20. Kazahskiy fol'klor v sobranii G.N. Potanina (arhivnye materialy i publikacii) [Kazakh Folklore in the Collection of G.N. Potanin (archival materials and publications)]. Alma-ata: "Science", 1972. 379 p. (In Russian)

21. Hafiz-i Tanysh Bukhari. Sharaf-name-yi shakhi (Kniga shakhskoy slavy) [Sharafname-yi shahi (Book of Shah's Glory)]. Ch. 1. Salahedinova M.A. (tr.). Moscow: "Science", 1983. 534 p. (In Russian)

22. Khanykov N.V. Opisanie Bukharskogo khanstva [Description of the Bukharan Khanate]. St. Petersburg, 1843. 284 p. (In Russian)

23. Holzwarth W. The Uzbek State as reflected in eighteenth-century Bukharan sources. Asian Studies. 2006, no. 60/2, pp. 342-346.

24. Holzwarth W. Relations between Uzbek Central Asia, the Great Steppe and Iran, 1700-1750. Shifts and Drifts in Nomad-Sedentary Relations. Leder S. and Streck B. (eds). Wiesbaden: Dr. Ludwig Reichert Verlag, 2005, pp. 179-216.

25. Khoroshkhin A.P. Sbornik statey, kasayushikhsya do Turkestanskogo kraya [Collection of Articles Related to Turkestan Krai.]. St. Petersburg, 1876. 532 p. (In Russian)

26. Karmysheva B.Kh. Polevoy dnevnik № 4, 1960 god [Field diary, no. 4, 1960]. Nauchnyy arkhiv Instituta etnologii i antropologii imeni N.N. Miklukho-Maklaya RAN [N.N. Miklukho-Maklay Institute of Ethnology and Anthropology of the Russian Academy of Sciences]. Fund 23, inventory 7, file 4753. (In Russian)

27. Kopeev, Dzhusip Meshkhur. Shigarmalary [Works]. Vol. 11. Pavlodar: Eko, 2007. 418 p. (In Kazakh)

28. Kozin S.A. Sokrovennoe skazanie. Mongol'skaya khronika 1240 goda [The Secret History. Mongolian Chronicle of 1240]. Vol. 1. Moscow; Leningrad, 1941. 619 p. (In Russian)

29. Kügelgen A. von. Legitimacija sredneaziatskoj dinastii mangitov v proizvedenijah ih istorikov (XVIII-XIX vv.) [The Legitimization of the Central Asian Dynasty of the Manghyts in the Works of Historians (eighteenth and nineteenth centuries)]. Almaty: "Dayk-Press", 2004. 516 p. (In Russian)

30. Kurbangali Khalid. Tauarikh khamsa (bes tarikh). Taurih-i hamsa-i sharki [Five Histories. History of Five Orients]. Totenaev B. and Joldasov A. (tr.). Almaty: "Kazakhstan”, 1992. (In Kazakh)

31. Lhamsuren Munkh-Erdenep. Where did the Mongol Empire come from? Medieval Mongol ideas of people, state and Empire. Inner Asia. 2011, vol. 13, no. 2.

32. Lee, Joo-Yup. Qazaqlïq, or Ambitious Brigandage, and the Formation of the Qazaqs: State and Identity in post-Mongol Central Eurasia. Brill, 2015.

33. Malikov A.M. Tyurkskie etnononimy i etnotoponimy doliny Zeravshana (XVIII nachalo $X X$ v.). [Turkic Ethnonyms and Ethnoponyms of the Zerafshan Valley (from the eighteenth to early twentieth centuries)]. Tashkent: Muharrir nashriyoti, 2018. 216 p. (In Russian)

34. Malikov A.M. Iz istorii qirkov Sredneaziatskogo mezhdurechia [From the history of Qyrqs of Central Asian interfluve]. Materialy mezhdunarodnoy konferentsii, posviashennoy 175-letiyu Ch.Ch. Valikhanova. [Proceedings of the International Conference Devoted to the $175^{\text {th }}$ Anniversary of Chokan Valikhanov]. Almaty: Tarikh taghylymy, 2010, pp. 158-165. (In Russian)

35. Malikov A. Semerkant Bölgesindeki Özbeklerin Etnik Tarihi [The ethnic history of Uzbeks of the Samarkand region]. Türkler [Turks]. Volume VIII. Ankara: Yeni Türkiye Yay., 2002, pp. 617-623. (In Turkish)

36. Maslyuzhenko D.N., Ryabinina E.A. Klimaticheskiy i epidemicheskiy faktory v istorii Sibirskoy gosudarstvennosti Shibanidov v XV-XVI vv. [Climatic and epidemic factors in the history of the Siberian statehood of the Shibanids in the fifteenth and six- 
teenth centuries]. Epidemii $i$ prirodnye kataklizmy $v$ Zolotoy Orde $i$ na sopredel'nykh territoriyakh (XIII-XVI vv.). Sbornik nauchnykh statey [Epidemics and Natural Disasters in the Golden Horde and Adjacent Territories (from the thirteenth to sixteenth centuries). Collected Studies]. Kazan: Marjani Institute of History of Tatarstan Academy of Sciences, 2018, pp. 229-240. (In Russian)

37. Materialy po istorii kyrgyzov i Kyrgyzstana [Materials on the History of the Kyrgyz and Kyrgyzstan]. Vol. 1. Romodin V. (ed.). Moscow: "Science", 1973. 279 p. (In Russian)

38. Mirgaleev I. Smuta 60-70-kh godov XIV veka [The Trouble Time of the 1360 s70s]. Zolotaya Orda v mirovoy istorii. Kollektivnaya monografiya [The Golden Horde in World History. Collective Monograph]. Kazan: Marjani Institute of History of Tatarstan Academy of Sciences, 2016. 968 p. (In Russian)

39. Mirza Abdalazim Sami. "Tarikh-i salatin-i manghitiya” dar as-saltana-i Bukhara$i$ sharif (Istoriya mangytskikh gosudarey) [History of the Manghit Sovereigns]. Epifanova L.M. (tr.). Moscow, 1962. 329 p. (In Russian)

40. Mirza Salimbek. Tarikh-i Salimi (Istochnik po istorii Bukharskogo emirata) [Source on the History of the Bukharan Emirate]. Norkulov N. (tr.) Tashkent: "Academy", 2009. 330 p. (In Russian)

41. Mukammad Haydar Dughlat. Tarikh-i Rashidi. Urunbaeva A., Dzhalilova R.P., and Epifanova L.M. (tr.). Tashkent: Fan, 1996. (In Russian)

42. Munshi Muhammad Yusuf. Mukim-khanskaya istoriya [Mukim-Khan's History]. Semenov A.A. (tr.). Tashkent, 1956. 300 p. (In Russian)

43. Paksoy H.B. Z.V. Togan: The origins of the Kazakhs and the Özbeks. Central Asian Survey. 1992, no. 11/3, pp. 83-100.

44. Potanin G.N. Prichina vozniknoveniya kazak-kirgizov [The reason of origin of Kazakh-Kyrgyzes]. Potanin G.N. Izbrannye sochineniya v trekh tomakh, Tom 3: Trudy po istorii, etnografii i fol'kloru [Selected Works in Three Volumes, Vol. 3: Works on History, Ethnography, and Folklore]. Pavlodar: "Eko", 2005. (In Russian)

45. Razhabov M. Azhdodingizni bilasizmi? [Do You Know Your Ancestors?]. Samarkand, 1997. (In Uzbek)

46. Sadr-i Ziya. Bayon-i qabail va urugh va taksin v Mazhmua-i tazakar. Sobranie pamyatnykh zapisey [Collection of Memorial Notes]. Institut Vostokovedeniya AN Uzbekistana. Inventarnyy nomer № 2193/11 [Institute of Oriental Studies of the Academy of Science of Uzbekistan. No. 2193/11]. (In Persian)

47. Semenov A.A. K voprosu o proiskhozhdenii i sostave uzbekov Sheibani-khana [On the origin and composition of Sheibani Khan's Uzbeks]. Trudy Akademii Nauk Tazhikskoy SSR [Works of Academy of Sciences of the Tajik SSR]. Vol. 12. Stalinabad, 1953, pp. 3-37. (In Russian)

48. Serebrennikov A.G. Turkestanskiy krai. Sbornik materialov dlya istorii ego zavoevaniya, T. 17: $1864 \mathrm{~g}$. [The Turkestan Region. Materials for the History of Its Conquest, Vol. 17: 1864]. Part 1. Tashkent, 1914. 266 p. (In Russian)

49. Sobolev L.N. Geograficheskie i statisticheskie svedeniya o Zerafshanskom okruge s prilozheniem spiska naselennykh mest okruga [Geographical and statistical information about Zerafshan district with an appendix of the list of settlements of the district]. Zapiski imperatorskogo russkogo geograficheskogo obshchestva po otdeleniyu statistiki [Notes of the Imperial Russian Geographical Society for the Department of Statistics]. Vol. 4. St. Petersburg, 1874. (In Russian)

50. "Sobranie istoriy”. Majmu' at-tavarikh [Compendium of Chronicles]. Tagirzhanov A.T. (ed.). Leningrad: Leningrad State University, 1960. 188 p. (In Russian)

51. Solikh, Muhammad. Shayboniynoma [Sheibaniname]. Shodiev E. (ed.). Tashkent, 1989. (In Uzbek)

52. Shaniyazov K.S. O'zbek xalqining shakllanish zharayoni [The Process of Formation of Uzbek People]. Tashkent: Sharq Publ., 2001. 464 p. (In Uzbek) 
Malikov A. "92 Uzbek Tribes" in Official Discourses and the Oral Traditions from the $16^{\text {th }}$ to $19^{\text {th }}$ centuries 531

53. Sultanov T.I. K istoriografii etnopoliticheskoy istorii ulusov Dzhuchi i Chagataya [Historiography of the ethnic and political history of the Jochid and Chaghataid Uluses]. Zolotoordynskoe obozrenie=Golden Horde Review. 2017, vol. 5, no. 1, pp. 74-92. DOI: 10.22378/2313-6197.2017-5-1.74-92 (In Russian)

54. Sultanov T.I. Kochevye plemena Priaral'ya v XV-XVII vv. (voprosy etnicheskoy $i$ sotsial'noy istorii) [The Nomadic Tribes of the Aral Sea Region in the fifteenth and sixteenth centuries. (Questions of Ethnic and Social History)]. Moscow: "Science", 1982. 134 p. (In Russian)

55. Togan A.Z.V. Bugünkü Türkili (Türkistan) ve yakın tarihi. Cilt 1. Batı ve Kuzey Türkistan. Istanbul: Enderun kitabevi, 1981. (In Turkish)

56 Trepavlov V.V. Istoriya Nogayskoy Ordy [History of the Noghai Horde]. Kazan: "Kazan real estate", 2016. 764 p. (In Russian)

57 Trepavlov V.V. Stepnye imperii Evrazii: mongoly i tatary [Nomadic Empires of Eurasia: The Mongols and Tatars]. Moscow: "Quadriga", 2015. 368 p. (In Russian)

58. Tsentralniy gosudarstvenny arkhiv Respubliki Uzbekistan, Fond I-1, Opis' 34, Delo 8: Snosheniya s Bukharoi general-ad'jutanta K. Kaufmana [State Archive of the Republic of Uzbekistan, Fund I-1, Inventary 34, File 8: Adjutant General Kaufman's Relations with Bukhara]. (In Russian)

59. Turkestanskie vedomosti [Turkestan Gazette]. 1871, no. 39. (In Russian)

60. O'zbek poeziyasining antologiyasi [Anthology of Uzbek Poetry]. Tashkent, 1948. (In Uzbek)

61. Usama ibn Munkyz. Kniga nazidaniya. [Book of Edification]. Krachkovskiy Yu.I. (tr.). Moscow: "Oriental literature", 1958. 330 p. (In Russian)

62 Valihanov Ch.Ch. Sobranie sochineniy v pyati tomakh [Collected Works in Five Volumes]. Vol. 1. Alma-Ata: Academy of Sciences of KazSSR, 1961. (In Russian)

About the author: Azim Malikov - Cand. Sci. (History), Senior Researcher, Department of Asian Studies, Faculty of Arts, Palacky University Olomouc (511/8, Křižkovského Str., Olomouc 77147, Czech Republic); ORCID: 0000-0002-0173-2014. E-mail: azimmal2018@gmail.com

Received March 20, 2020 Accepted for publication August 28, 2020 Published September 29, 2020

\title{
«92 УЗБЕКСКИХ ПЛЕМЕНИ» В ОФИЦИАЛЬНЫХ ДИСКУРСАХ И УСТНОЙ ТРАДИЦИИ В ХVI-XIX ВВ.
}

\author{
А. Маликов \\ Университет Палацккого \\ Оломоуи, Чешская Республика \\ azimmal2018@gmail.com
}

Цель: выявить основные вариации использования термина «92 узбекских племени» в различных контекстах в официальных дискурсах и устной традиции в XVIXIX вв.

Материаль исследования: использованы сочинения среднеазиатских, персидских авторов XV-XIX вв.: Мухаммад Салиха, Фазлаллаха ибн Рузбихана Исфахани, Мирза 
Мухаммад Хайдара, Хафиз Таныша Бухари, Мухаммад Юсуфа мунши, Абдалазим Сами, Мирзо Салимбек, Садри Зиё, архивные материалы этнографа Б. Кармышевой, неопубликованная версия эпоса «Алпамыш» и архивные документы из Центрального Государственного архива Республики Узбекистан. Также подробно анализируются публикации российских, советских, постсоветских и зарубежных специалистов по истории Центральной Азии - Н. Ханыкова, Ч. Валиханова, А. Хорошхина, Л. Соболева, Г. Потанина, В.В. Бартольда, Ахмеда Валиди Тогана, П. Иванова, Б. Ахмедова, Т. Султанова, П. Голдена, Д. Девиза, В. Трепавлова, В. Хольцварса, А. Алексеева, Б. Бабаджанова.

Результаты и научная новизна: термин «92 узбекских племени», появившийся в $\mathrm{XV}$ в. в Дешт-и Кыпчаке, в последующие столетия стал использоваться с самым различным смыслом в зависимости от политического и культурного контекста.

Значительная роль представителей племен, выходщев из бывшей Золотой Орды, в политической жизни среднеазиатских ханств с XVI века, миграции кочевых племен из Дашт-и Кипчака в Мавераннахр на протяжении XVI века, а затем основание в XVIII веке в среднеазиатских ханствах династий из среды этих племен обеспечили актуальность и относительно широкое использования термина «92 узбекских племени».

Для полукочевых племен этих ханств принадлежность к «92 узбекским племенам» означала в определеных случаях привилегированное положение и более высокий социальный, экономический статус. В определенных случаях выражение «92 узбекских племени» использовался с политическим смыслом для легитимации правящих узбекских династий мангытов, мингов, а также, следуя давней традиции, возможно, преследуя политические цели, подчеркивались давние связи между казахами, ногайцами, узбеками и каракалпаками. Наряду с числом 92 сосуществовали такие числа, как 32 и 96 племен, которым придавались другие значения.

Ключевые слова: Золотая Орда, Узбеки, Казахи, Центральная Азия, 92 узбекских племени, Дашт-и Кипчак, Шибаниды, Бухара, Кокандское ханство, дискурсы, легитимация

Для цитирования: Malikov A. "92 Uzbek Tribes" in Official Discourses and the Oral Traditions from the sixteenth to nineteenth centuries // Золотоордынское обозрение. 2020. T. 8, № 3. C. 515-532. DOI: 10.22378/2313-6197.2020-8-3.515-532

Благодарности: Работа выполнена в рамках проекта Европейского фонда регионального развития «Синоязычные границы: взаимодействие на рубежах» (CZ.02.1.01/0.0/0.0/16_019/0000791). Выражаю особую благодарность редактору и анонимным рецензентам за их комментарии и замечания.

Сведения об авторе: Азим Маннонович Маликов - кандидат исторических наук, старший научный сотрудник отдела Азиатских исследований Университета Палацкого, Оломоуц (77147, ул. Крижковская, 511/8, Оломоуц, Чешская Республика); ORCID: 0000-0002-0173-2014. E-mail: azimmal2018@gmail.com 